\title{
APPLICATION OF CHEMICALLY ACCELERATED BIOTREATMENT TO REDUCE RISK IN OIL-IMPACTED SOILS
}

\author{
Prepared by \\ J.R. Paterek \\ W.W. Bogan \\ L.M. Lahner \\ V. Trbovic \\ E. Korach
}

SEMI-ANNUAL REPORT

(NOVEMBER 2000 THRU APRIL 2001)

GAS TECHNOLOGY INSTITUTE

1700 South Mount Prospect Road

Des Plaines, Illinois 60018

IGT Project 30722

ALL TASKS

For

DEPARTMENT OF ENERGY

and

GAS TECHNOLOGY INSTITUTE

DOE Project Manager

Nancy Comstock

DOE Contract No. DE-AC26-99BC15223

FERC Project Manager

Steve Wiersma

May 2001 


\section{TABLE OF CONTENTS}

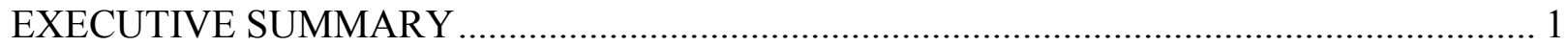

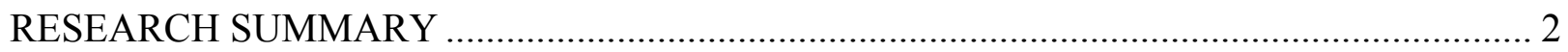

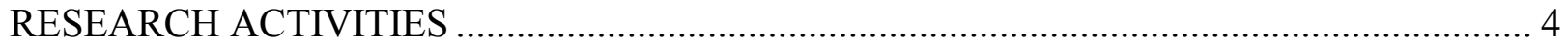

Determination of Nutrient Limitations in E\&P Soils ............................................... 4

Solid-State Remediation of E\&P Soils .................................................................... 5

Toxicity Determinations with Microtox Solid-Phase Test............................................ 7

Use of TEP by Individual Bacterial Strains ............................................................. 7

PAH Growth Range Of Mycobacterium austroafricanum ........................................... 7

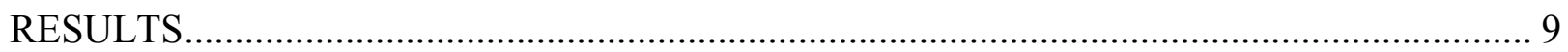

Determination of Nutrient Limitations in E\&P Soils ............................................... 9

Solid-State Remediation of E\&P Soils .............................................................. 11

Toxicity Determinations with Microtox Solid-Phase Test.......................................... 11

Use of TEP by Individual Bacterial Strains .......................................................... 11

PAH Growth Range Of Mycobacterium Austroafricanum .......................................... 13

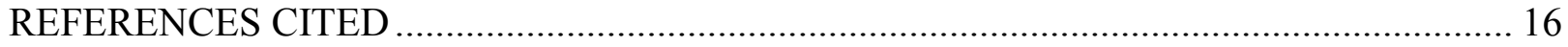

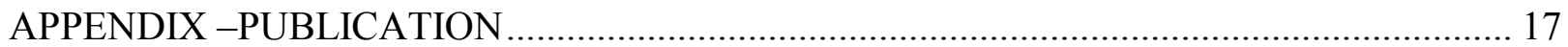




\section{EXECUTIVE SUMMARY}

The results presented within are a summary of research activities from November 2000 until the end of April 2001 between the Gas Technology Institute (GTI), formerly known as Institute of Gas Technology, Department of Energy (DOE), and Federal Energy Regulatory Commission (FERC) funds managed by the Gas Research Institute (now a component of GTI). This report incorporates the data presented not in the first semiannual report or first annual report. Chemically Accelerated Biotreatment (CAB) processes have been proven successful for the treatment of Manufactured Gas Plant (MGP) site wastes; therefore the technology is being investigated for application to wastes associated with petroleum/natural gas exploration and production (E\&P) sites. In addition, the application of $\mathrm{CAB}$ is being evaluated using risk-based analysis, along with traditional analytical chemistry testing, for endpoint determinations. These results will be applied to the development of environmentally acceptable endpoints (EAE) in comparison to strictly analytical assessments.

During this first 6 months of the second year, work was conducted in five major areas of the project:

- Determining the nutrient limitations which constrain the abilities of indigenous bacteria in two crude oil-contaminated soils to degrade and mineralize aliphatic hydrocarbons (e.g. hexadecane) representative of crude oil

- Applying these findings to solid-state (soil flask and soil column) experiments to attempt to increase oil degradation through use of nutrient amendments (especially gaseous $\mathrm{N}$ and/or P sources)

- Establishing the Microtox ${ }^{\circledR}$ solid-phase assay as a suitable tool for monitoring toxicity reductions in oil-impacted soils during remediation experiments.

- Determining the ability of individual strains of PAH-degrading bacteria to use triethylphosphate (TEP) as a phosphorus source, and assessing the possible effect of carbon source on this ability.

- Documenting the ability of a strain of Mycobacterium austroafricanum to grow on and/or degrade a range of highly-recalcitrant 5- and 6-ring PAHs. 


\section{RESEARCH SUMMARY}

Title Application of chemically accelerated biotreatment to reduce risk in oilimpacted soils

Contractors U.S. Department of Energy

DOE Contract No.

Institute of Gas Technology

GRI Contract No. 8054

Principal

Investigator

J. Robert Paterek

Report Period November 2000 through April 2001

Objective The overall program objective is to develop and evaluate integrated biological/physical/chemical co-treatment strategies for the remediation of wastes associated with the exploration and production of fossil energy. The specific objectives of this project are: chemical accelerated biotreatment (CAB) technology development for enhanced site remediation, application of the risk based analyses to define and support the rationale for environmental acceptable endpoints (EAE) for exploration and production wastes, and evaluate both the technological technologies in conjugation for effective remediation of hydrocarbon contaminated soils from E\&P sites in the USA.

Technical

Approach

This project is part of the program of IGT/GRI in an effort to develop and enhance the microbiological approach to the degradation of wastes present at natural gas/petroleum production and exploration sites. It is of primary importance to this program to develop the capability to biologically degrade all the mobile or available fraction of the toxic or hazardous hydrocarbons present at these sites, including the "recalcitrant" aromatic moieties, which include those compounds containing elements other than carbon in the rings. To achieve this goal, research efforts focuses on enhancing the growth of microbial cultures with capabilities for biodegrading these compounds, aiding microbial activities by sequential or concurrent chemical oxidation of recalcitrant hydrocarbon moieties, determining the mobility and toxicity of the various hydrocarbon components in E\&P wastes, in the conducting parametric studies to maximize detoxification of soils to meet "environmentally acceptable endpoints," and providing scientific and engineering supports for future application of in-situ, landfarming, and bioslurry reactor treatment technologies. Research efforts under the GRI project focused on evaluating the performance of selected cultures under a variety of bioremediation conditions in simulated "real world" and field conditions found at representative E\&P sites. 
Activities Experiments were conducted during this reporting period to extend the application of gaseous nutrient (particularly phosphorus) sources to support bioremediation of crude oil (i.e. aliphatic hydrocarbon)-contaminated soils. Toxicological experiments have been used to verify that suitable assays are in place for monitoring the detoxification of these soils during solid-phase bioremediation experiments, which will be run during the next six-month period. 


\section{RESEARCH ACTIVITIES}

\section{DETERMINATION OF NUTRIENT LIMITATIONS IN E\&P SOILS}

As a first step towards determining the ability of gaseous nutrient sources to support degradation of oil-derived aliphatic hydrocarbons in petroleum-contaminated E\&P soils, it was necessary to first identify a candidate soil which was suitably nutrientlimited. This was accomplished through the use of slurry-phase cultures, as we have used throughout this project to assess nutrient effects on contaminant degradation under "ideal" conditions (i.e. in systems where issues such as nutrient and contaminant bioavailability were minimized).

Homogenized soil samples $(500 \mathrm{mg})$ were mixed with $50 \mathrm{ml}$ sterile media $(0.1 \mathrm{ml}$ Wolfe's Vitamins ( $2 \mathrm{mg} \cdot \mathrm{l}^{-1}$ biotin, $2 \mathrm{mg} \cdot \mathrm{l}^{-1}$ folic acid, $10 \mathrm{mg} \cdot \mathrm{l}^{-1}$ pyridoxine $\mathrm{HCl}, 5 \mathrm{mg} \cdot \mathrm{l}^{-}$ ${ }^{1}$ thiamine $\mathrm{HCl}, 5 \mathrm{mg} \cdot \mathrm{l}^{-1}$ riboflavin, $5 \mathrm{mg} \cdot 1^{-1}$ nicotinic acid, $5 \mathrm{mg} \cdot 1^{-1}$ pantothenic acid, 0.1 $\mathrm{mg} \cdot \mathrm{l}^{-1}$ cyanocobalamine, $5 \mathrm{mg} \cdot 1^{-1} \mathrm{p}$-aminobenzoic acid, $5 \mathrm{mg} \cdot \mathrm{l}^{-1}$ thioctic acid), $0.1 \mathrm{ml}$ Trace Minerals (100 mg $\cdot 1^{-1} \mathrm{ZnSO}_{4}, 300 \mathrm{mg} \cdot \mathrm{l}^{-1} \mathrm{H}_{3} \mathrm{BO}_{3}, 300 \mathrm{mg} \cdot \mathrm{l}^{-1} \mathrm{CoCl}, 10 \mathrm{mg} \cdot \mathrm{l}^{-1} \mathrm{CuCl}$ ) and $0.8 \mathrm{ml} \mathrm{N}$ - \& P-free (pH 7.2) Winogradsky medium (62.5 g. $1^{-1} \mathrm{MgSO}_{4} \cdot 7 \mathrm{H}_{2} \mathrm{O}, 31.25$ $\mathrm{g} \cdot \mathrm{l}^{-1} \mathrm{NaCl}, 1.25 \mathrm{~g} \cdot \mathrm{l}^{-1} \mathrm{FeSO}_{4}, 1.25 \mathrm{~g} \cdot \mathrm{l}^{-1} \mathrm{MnSO}_{4}$ ) per $100 \mathrm{ml}$ of sterile deionized water) in 125 - $\mathrm{ml}$ serum bottles. Cultures were incubated at room temperature (approx. $25^{\circ} \mathrm{C}$ ), with constant shaking at $170 \mathrm{rpm}$.

In order to assess the degree of $\mathrm{N}$ - and P-limitation on PAH degradation inherent in each soil, ${ }^{14} \mathrm{C}$-hexadecane mineralization was measured in cultures of each of two crude oil-contaminated wellhead soils which received no supplemental $\mathrm{N}$ or $\mathrm{P}, \mathrm{N}$ only (as $\mathrm{NH}_{4} \mathrm{Cl}$ ), $\mathrm{P}$ only (as $\mathrm{KH}_{2} \mathrm{PO}_{4}$ ), or both $\mathrm{N}$ and $\mathrm{P}$. $\mathrm{CO}_{2}$ traps were made by wrapping stainless steel wire around the necks of $12 \times 32 \mathrm{~mm}$ borosilicate glass autosampler vials and pushing the wire through $20-\mathrm{mm}$ Teflon silicone-lined septa. These assemblies were placed in the serum bottles, which were then crimped with aluminum seals. Syringes were used to inject $1 \mathrm{ml}$ of $0.5 \mathrm{M} \mathrm{NaOH}$ into each $\mathrm{CO}_{2}$ trap. Periodically, the $\mathrm{CO}_{2}-$ containing $\mathrm{NaOH}$ solution was withdrawn from the traps, mixed with $5 \mathrm{ml}$ of Ultima Gold ${ }^{\circledR}$ high-flashpoint LSC cocktail solution (Packard, Meriden, CT), and counted in a 
liquid scintillation counter (Packard Model 2200CA Tri-Carb). Fresh NaOH was then added to the $\mathrm{CO}_{2}$ traps. Cultures containing ${ }^{14} \mathrm{C}$ - hexadecane typically received $c a$. $60,000-80,000 \mathrm{dpm}$ of labeled hexadecane in $20 \mu \mathrm{l}$ of methanol.

Six combinations were then investigated for nitrogen $(\mathrm{N})$ and phosphorus $(\mathrm{P})$ supplementation: $\mathrm{NH}_{4} \mathrm{Cl} / \mathrm{KH}_{2} \mathrm{PO}_{4} ; \mathrm{N}_{2} \mathrm{O} / \mathrm{KH}_{2} \mathrm{PO}_{4} ; \mathrm{NH}_{4} \mathrm{Cl} / \mathrm{TEP} ; \mathrm{NH}_{4} \mathrm{Cl} / \mathrm{TBP} ; \mathrm{N}_{2} \mathrm{O} / \mathrm{TEP}$ and $\mathrm{N}_{2} \mathrm{O} / \mathrm{TBP}$. Within each condition, duplicate cultures were employed. In all cases, addition of $\mathrm{N}$ and $\mathrm{P}$ sources was normalized on a molar basis to provide $9.2 \mathrm{mM} \mathrm{N}$ and $3.7 \mathrm{mM}$ P. When $\mathrm{N}_{2} \mathrm{O}$ was used, it was added by injection to sealed bottles.

\section{SOLID-STATE REMEDIATION OF E\&P SOILS}

The preferred configuration for evaluation of gaseous nutrient compounds in solid-phase systems is shown in Figure 1 (in practice, an air inlet line is generally hooked to a bubbler or airstone in the flask, such that air is flushed through the system to facilitate volatilization of the nutrient). Soil is sampled (top and bottom of the column) before and after TEP addition to verify (by analyzing total $\mathrm{P}$ ) that all supplemented $\mathrm{P}$ was captured by the soil column. Periodic sampling can then be done of soil at both ends of the column to assess degradation of TPH and/or PAH, and total bacterial populations (both total heterotrophs and alkane- and/or PAH-degraders) and activity. 


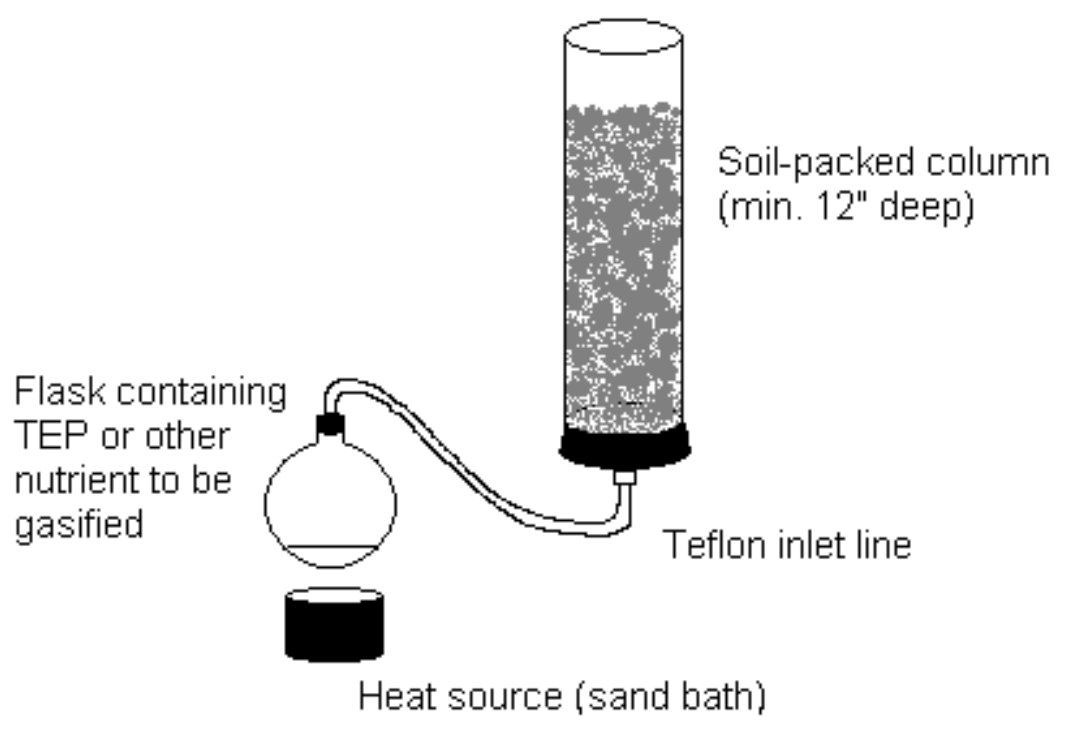

Figure 1 - System used for evaluating effectiveness of gasifiable nutrients (such as triethylphosphate) in solid-phase systems (vadose-zone soils).

Because the first experiments of this nature, in which $\mathrm{N}$ and $\mathrm{P}$ (as ammonium nitrate and either TEP or $\mathrm{KH}_{2} \mathrm{PO}_{4}$, respectively) showed very low bacterial populations after one week (4 to 5 orders of magnitude lower than water-only controls), we have switched to an initial evaluation of nutrient-amendment systems prior to initiating column studies. These are being conducted in stoppered flasks, with sidearm reservoirs containing $\mathrm{NaOH}$ as a $\mathrm{CO}_{2}$ trap. Radiolabeled hexadecane (as a model aliphatic hydrocarbon is added to the soil, and evolution of ${ }^{14} \mathrm{CO}_{2}$ over time is taken as a measure of the performance of the system under various supplementation conditions. Once nutrient-amendment conditions can be defined which appear to support contaminant degradation in this screening system, they will then be applied in the column system shown above to fully study the effects of gaseous nutrients on hydrocarbon degradation and its underlying microbiology. 


\section{TOXICITY DETERMINATIONS WITH MICROTOX SOLID-PHASE TEST}

In order to determine whether the Microtox solid-phase test would be suitable for assessing the potential toxicity of the $\mathrm{E} \& \mathrm{P}$ soils to be used in solid-state remediation experiments and in determinations of environmentally acceptable endpoints, this assay was run on one of the oil-contaminated soils $(\mathrm{AB})$. All procedures were followed according to manufacturer's instructions, and clean coarse sand (the same sand used to dilute the soil for column experiments) was used as a control.

\section{USE OF TEP BY INDIVIDUAL BACTERIAL STRAINS}

The abilities of individual PAH-degrading isolates to utilize TEP as a phosphorus source were assessed by generating growth curves in $96-$ well microplates. Four parallel sets of cultures were run: One set contained glucose as the sole C source and TEP as the sole $\mathrm{P}$ source; other sets contained glucose $/ \mathrm{KH}_{2} \mathrm{PO}_{4}$, phenanthrene/TEP, and phenanthrene $/ \mathrm{KH}_{2} \mathrm{PO}_{4}$. All conditions were tested in triplicate. Absorbance measurements were taken periodically, until it could be determined that the stationary growth phase was reached for each culture under each condition. Thus, the data collected in this experiment represents the maximal growth (biomass) attainable under each condition.

\section{PAH GROWTH RANGE OF MYCOBACTERIUM AUSTROAFRICANUM}

In experiments which we have reported previously, we attempted to determine the range of PAH compounds which could be degraded by M. austroafricanum by conducting growth experiments in 96-well microplates. Under a fume hood, individual PAHs are dissolved in solvents and added to the wells, and solvent is allowed to evaporate overnight. The amount of PAH actually deposited into the wells ranged from $0.2 \mu \mathrm{g}$ to $17.2 \mu \mathrm{g}$. A small amount of bacteria (one small colony from a phenanthrene-sublimated gel plate) was added to approximately $20 \mathrm{ml}$ of mineral salts medium and vortexed; 180 $\mu 1$ aliquots of the resultant bacterial suspension were then added to each PAH-containing well. Iodonitrotetrazolium violet (INT) was added to each well at the start of the experiment at a concentration of $0.2 \mathrm{mg} \cdot \mathrm{ml}^{-1}$. In the presence of active respiring bacteria, 
INT forms a reddish-purple precipitate when reduced to insoluble formazan. Plates were thus observed visually; wells with red or purple precipitate were scored as positive. Separate wells containing media, INT and bacteria were used as negative controls. During incubation, microplates were sealed in zip-lock bags, to reduce any evaporation loss, and stored at room temperature.

We have also employed several other methods to corroborate the results which we obtained in INT experiments. In the first of these, high-molecular-weight PAHs which emerged from this experiment as probable growth substrates were sublimated onto plates (either noble gel agar or a yeast extract/peptone/starch agar) which had been spread-plated with $M$. austroafricanum. These were then observed over a period of several weeks to detect clearing zones.

An additional experiment was conducted which used the same approach as the INT microplate experiment described above, except that INT was omitted, and growth of the bacterium (assessed as absorbance at $\lambda=600 \mathrm{~nm}$ ) was monitored periodically over a period of approximately 10 days. 


\section{RESULTS}

\section{DETERMINATION OF NUTRIENT LIMITATIONS IN E\&P SOILS}

The extents of hexadecane mineralization in slurry microcosms containing indigenous microbes from the two oil-contaminated E\&P soils are shown in Figure 2 below. Both of the two soils tested evidenced very significant limitations for nitrogen; this was most notable in soil $\mathrm{AB}$, in which the amount of ${ }^{14} \mathrm{CO}_{2}$ released through hexadecane mineralization was approximately 17 -fold higher in $\mathrm{N}$-supplemented conditions versus those with no nutrient addition. Similar patterns were seen in soil C, although the degree of stimulation by supplemental $\mathrm{N}$ was not as high as in soil $\mathrm{AB}$. The other notable difference between the two soils was in the significance of the phosphorus limitation: While soil $\mathrm{AB}$ supported significantly higher mineralization when both $\mathrm{N}$ and $\mathrm{P}$ were added (vs. $\mathrm{N}$ only), the two conditions behaved virtually identically in soil $\mathrm{C}$.
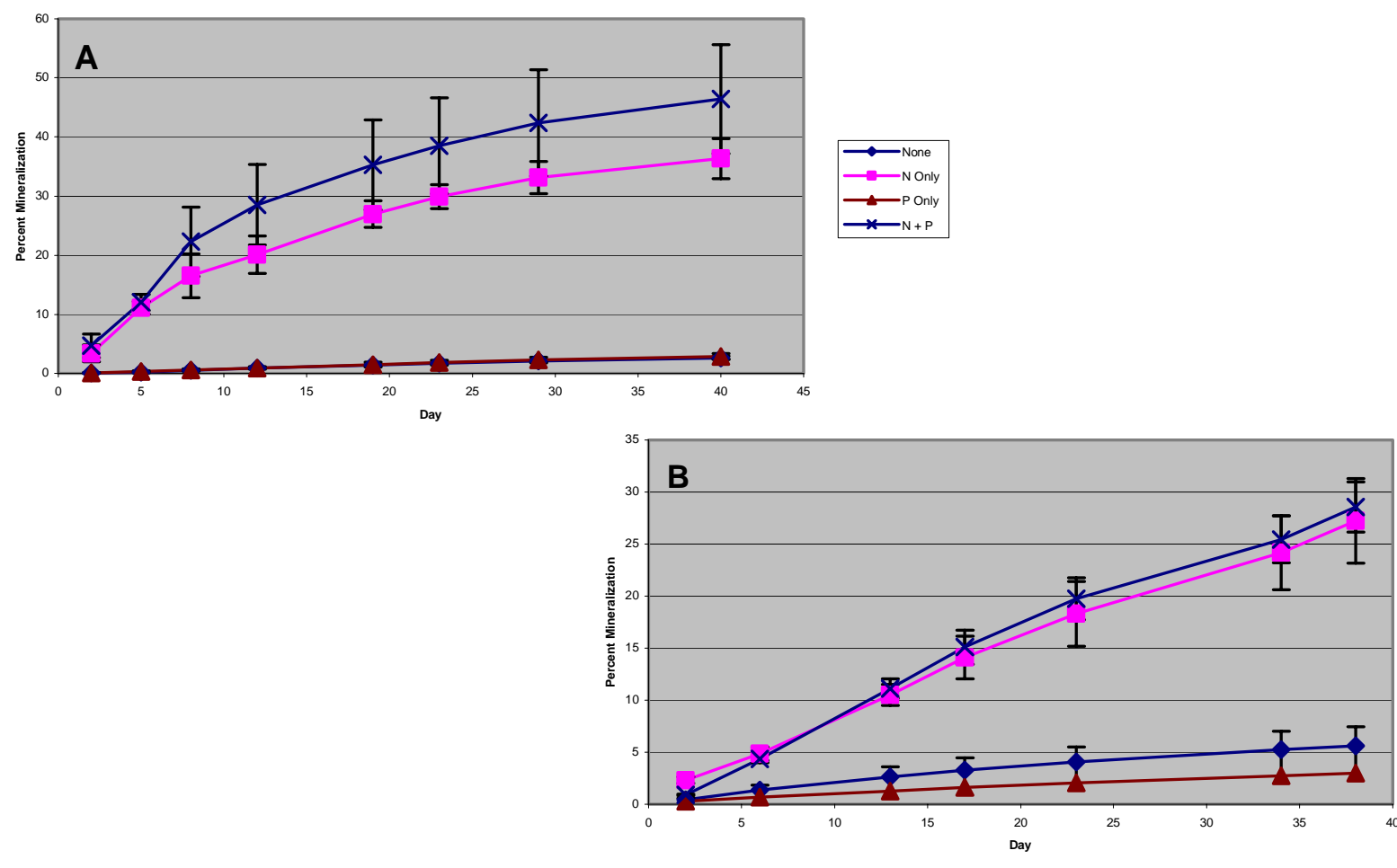

Figure 2 - Effects of $\mathrm{N}$ and $\mathrm{P}$ addition on mineralization of hexadecane by microbes indigenous to oilcontaminated E\&P soils. Graph A = Soil AB; Graph B = Soil C 
Thus, it can be concluded that, in terms of degradation of oil-related hydrocarbons, the microbes in soil AB are strongly limited by their available $\mathrm{N}$ supply, and, when $\mathrm{N}$ is added in sufficient levels, a significant $\mathrm{P}$ limitation also becomes apparent. In contrast, soil $\mathrm{C}$ contained sufficient $\mathrm{P}$ supplies that $\mathrm{N}$ alone was the limiting factor for hydrocarbon degradation. Given that the goal of the experiments undertaken here was to evaluate potential gaseous $\mathrm{N}$ and $\mathrm{P}$ sources for their effects on hydrocarbon remediation, soil $\mathrm{AB}$ was selected for further work, due to the fact that it was found to be limited for both nutrients.

The ability of the indigenous microbes in soil AB to mineralize hexadecane was then investigated under different conditions of nitrogen and phosphorus supplementation. The results of this experiment are shown in Figure 3 below.

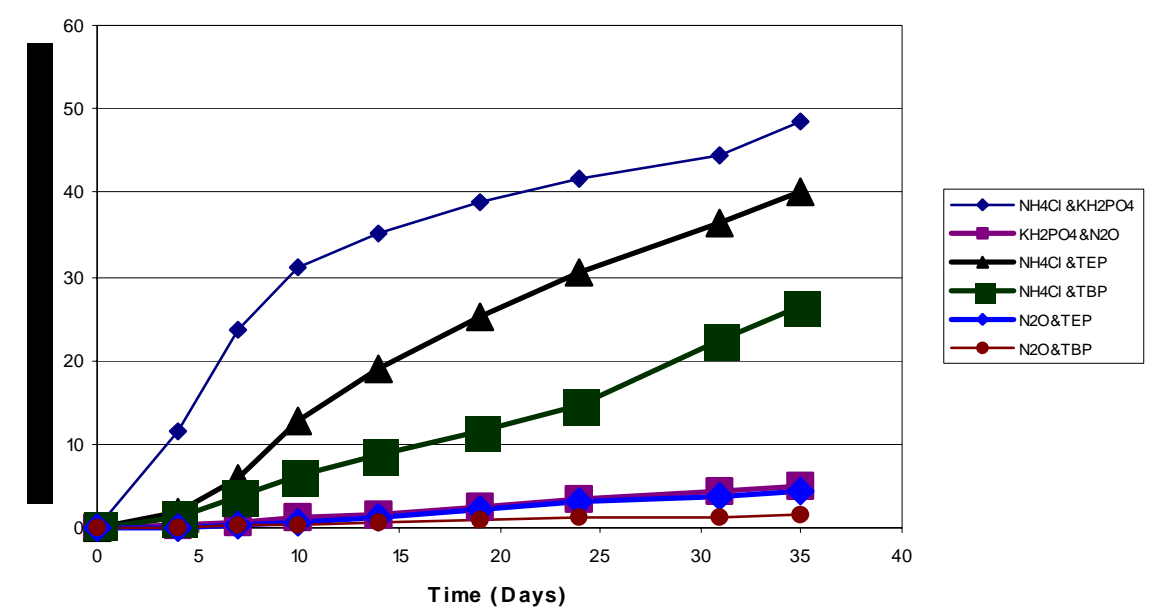

Figure 3 - Ability of gaseous $\mathrm{N}$ and $\mathrm{P}$ compounds to overcome nutrient limitations and support hexadecane mineralization by indigenous microbes in soil AB.

These results clearly show that use of TEP as an alternative to inorganic phosphate to support remediation of aliphatic hydrocarbons is quite feasible in this soil; mineralization of hexadecane with TEP as a phosphorus source was nearly equal to that with $\mathrm{KH}_{2} \mathrm{PO}_{4}$. TBP supported considerably less hexadecane mineralization, and use of 
$\mathrm{N}_{2} \mathrm{O}$ as a source of $\mathrm{N}$ was found to be extremely deleterious to the performance of the system.

\section{SOLID-STATE REMEDIATION OF E\&P SOILS}

Thus far, none of the nutrient-amendment regimes tested in solid-phase systems (soil flasks) has had any stimulatory effect on hexadecane mineralization. In fact, all nutrient additions (including either ammonium nitrate or ammonium chloride as $\mathrm{N}$ sources) completely abolished the release of ${ }^{14} \mathrm{CO}_{2}$ from cultures grown with radiolabeled hexadecane. Solid-state cultures which received water only did mineralize hexadecane, albeit at a considerably slower rate than in slurry-phase systems. This is true despite the fact that, on a per-soil-mass basis, the amount of $\mathrm{N}$ added to the solid-state cultures is very similar to that added to the slurry cultures in earlier experiments.

\section{TOXICITY DETERMINATIONS WITH MICROTOX SOLID-PHASE TEST}

The crude oil-contaminated soil which is to be used in the solid-state remediation experiments (Mt. Vernon $\mathrm{AB}$ ) has been subjected to toxicity testing by the Microtox solid-phase assay system. When the AB soil, diluted 1:1 with clean coarse sand (see above) was subjected to analysis, an $\mathrm{EC}_{50}$ value of $4200 \mathrm{mg} / \mathrm{l}( \pm 700 \mathrm{mg} / \mathrm{l}, \mathrm{n}=2)$ was obtained. For purposes of comparison, the corresponding value derived for the sand itself was $80,000( \pm 10,000) \mathrm{mg} / \mathrm{l}$. Thus, the oil-contaminated soil does demonstrate very significant toxicity through the Microtox assay (almost 20-fold more toxic than a comparable clean soil), and this assay is judged suitable for tracking toxicity reductions during treatment of the soil.

\section{USE OF TEP BY INDIVIDUAL BACTERIAL STRAINS}

The abilities of various bacterial strains to grow (on either glucose or phenanthrene as a sole source of carbon and energy) were compared with potassium phosphate $\left(\mathrm{KH}_{2} \mathrm{PO}_{4}\right)$ or TEP serving as the source of phosphorus. Results for this

experiment were as follows (all data are absorbance readings at $\lambda=600 \mathrm{~nm}$ during 
stationary phase of culture, and represent averages and standard deviations of triplicate determinations).

\begin{tabular}{|l|c|c|c|c|}
\hline & \multicolumn{2}{|c|}{ Glucose } & \multicolumn{2}{c|}{ Phenanthrene } \\
\hline & KH $_{2} \mathbf{P O}_{4}$ & TEP & KH$_{2} \mathbf{P O}_{4}$ & TEP \\
\hline Acidovorax & $1.041 \pm 0.11$ & $0.63 \pm 0.12$ & $0.20 \pm 0.01$ & $0.23 \pm 0.02$ \\
\hline Burkholderia 1 & $0.80 \pm 0.05$ & $0.86 \pm 0.21$ & $0.74 \pm 0.01$ & $0.49 \pm 0.03$ \\
\hline Burkholderia 2 & $0.57 \pm 0.16$ & $0.63 \pm 0.18$ & $0.54 \pm 0.09$ & $0.11 \pm 0.01$ \\
\hline Burkholderia 3 & $0.54 \pm 0.09$ & $0.49 \pm 0.01$ & & \\
\hline Pseudomonas 1 & $0.19 \pm 0.02$ & $0.13 \pm 0.01$ & $0.18 \pm 0.02$ & $0.13 \pm 0.01$ \\
\hline Pseudomonas 2 & $0.20 \pm 0.02$ & $0.25 \pm 0.02$ & $0.15 \pm 0.07$ & $0.19 \pm 0.16$ \\
\hline Pseudomonas 4 & $0.73 \pm 0.02$ & $0.93 \pm 0.07$ & $0.72 \pm 0.23$ & $0.52 \pm 0.19$ \\
\hline Pseudomonas 6 & $0.18 \pm 0.02$ & $0.11 \pm 0.02$ & $0.11 \pm 0.01$ & $0.06 \pm 0.02$ \\
\hline Sphingomonas 1 & $0.71 \pm 0.08$ & $0.49 \pm 0.02$ & $0.36 \pm 0.12$ & $0.24 \pm 0.02$ \\
\hline Sphingomonas 3 & $0.74 \pm 0.01$ & $0.58 \pm 0.04$ & & \\
\hline
\end{tabular}

Thus, several bacterial strains show marked preferences for $\mathrm{KH}_{2} \mathrm{PO}_{4}$ over TEP. The most notable examples of these include Acidovorax (when growing on glucose) and Pseudomonas strain \#6 and Burkholderia strain \#2 on phenanthrene; the latter is particularly significant, with nearly 5 -fold better growth occurring on inorganic phosphate than on TEP. 


\section{PAH GROWTH RANGE OF MYCOBACTERIUM AUSTROAFRICANUM}

A strain of Mycobacterium austroafricanum was isolated for its ability to degrade phenanthrene (producing clearing zones on phenanthrene-sublimated gel plates), and was found to also degrade the four-ring PAHs fluoranthene and pyrene as sole carbon and energy sources. As we have previously reported, we then assayed the PAH catabolic range of this strain by using 96-well plates, and assessing growth (respiration) via the deposition of reduced formazan deposits upon incubation with iodonitrotetrazolium violet (INT). This type of experiment led us to conclude that the strain in question was capable of growth on a wide variety of PAHs, including:

\section{3-Ring compounds}

Acenaphthene, Acenaphthylene, Anthracene, Fluorene, Phenanthrene

\section{4-Ring compounds}

Benz[a]anthracene, 2,3-Benzofluorene, Chrysene, Fluoranthene, Perylene, Pyrene, Triphenylene

\section{5-Ring compounds}

Benzo $[b]$ fluoranthene, 2,3-Benzofluoranthene, Benzo[ $[a]$ pyrene

\section{6- Ring compounds}

$\operatorname{Benzo}[g, h, i]$ perylene

Because of the novelty of this finding (in particular the ability of a bacterium to degrade 6-ring PAHs), we have sought to confirm this through other methods. When $M$. austroafricanum (pre-grown on plates with either phenanthrene or fluoranthene as sole source of carbon) was spread-plated onto gel plates which were then sublimated with 4to 6-ring PAHs, evidence of clearing zones was seen with the two benzofluoranthenes (benzo[ $b]$ fluoranthene and 2,3-benzofluoranthene), but not with other compounds. However, when agar plates composed of the yeast extract/peptone/soluble starch (YPS) medium (used for the growth of PAH-degrading Mycobacterium species) were employed instead, evidence of at least partial clearing zones was seen with all of the 4-, 5-, and 6ring compounds listed above; this was frequently very significant, as can be seen in the case of the clearing zones formed by colonies degrading benzo[ $g, h, i]$ perylene in Figure 4 . 
The apparent contradiction in these two sets of results may be explained by the fact that some bacteria have been found to be incapable of establishing colonies, when grown on hydrocarbon substrates, from a single cell. Other authors have postulated this to be due to the inability of single cells to attach to hydrocarbon crystals (or liquid/liquid interfaces in the case of oils) strongly enough to initiate their degradation, and have found that, in some cases, as many as ten or more cells may be required to initiate a viable colony under these conditions. Because the bacteria grown on YPS plates are able to use components of this medium as carbon sources, they may be able to overcome this limitation, and give rise to colonies which are capable of degrading the sublimated PAH.

We have also conducted a growth-curve experiment (in 96-well microplates) to determine the ability of $M$. austroafricanum to grow on various high-molecular-weight PAH species. Results of this experiment are given in Figure 5.

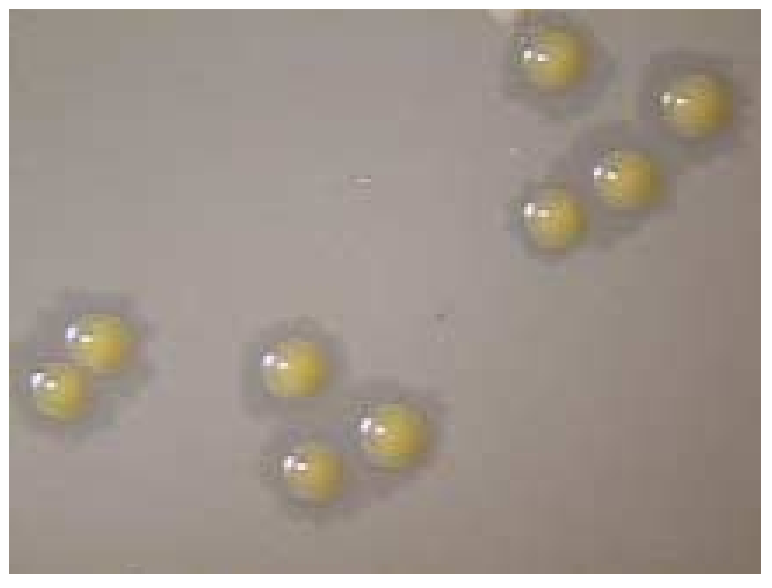

Figure 4 - Clearing of benzo[ $g, h, i]$ perylene by colonies of Mycobacterium austroafricanum during growth on yeast extract/peptone/starch agar plates. 

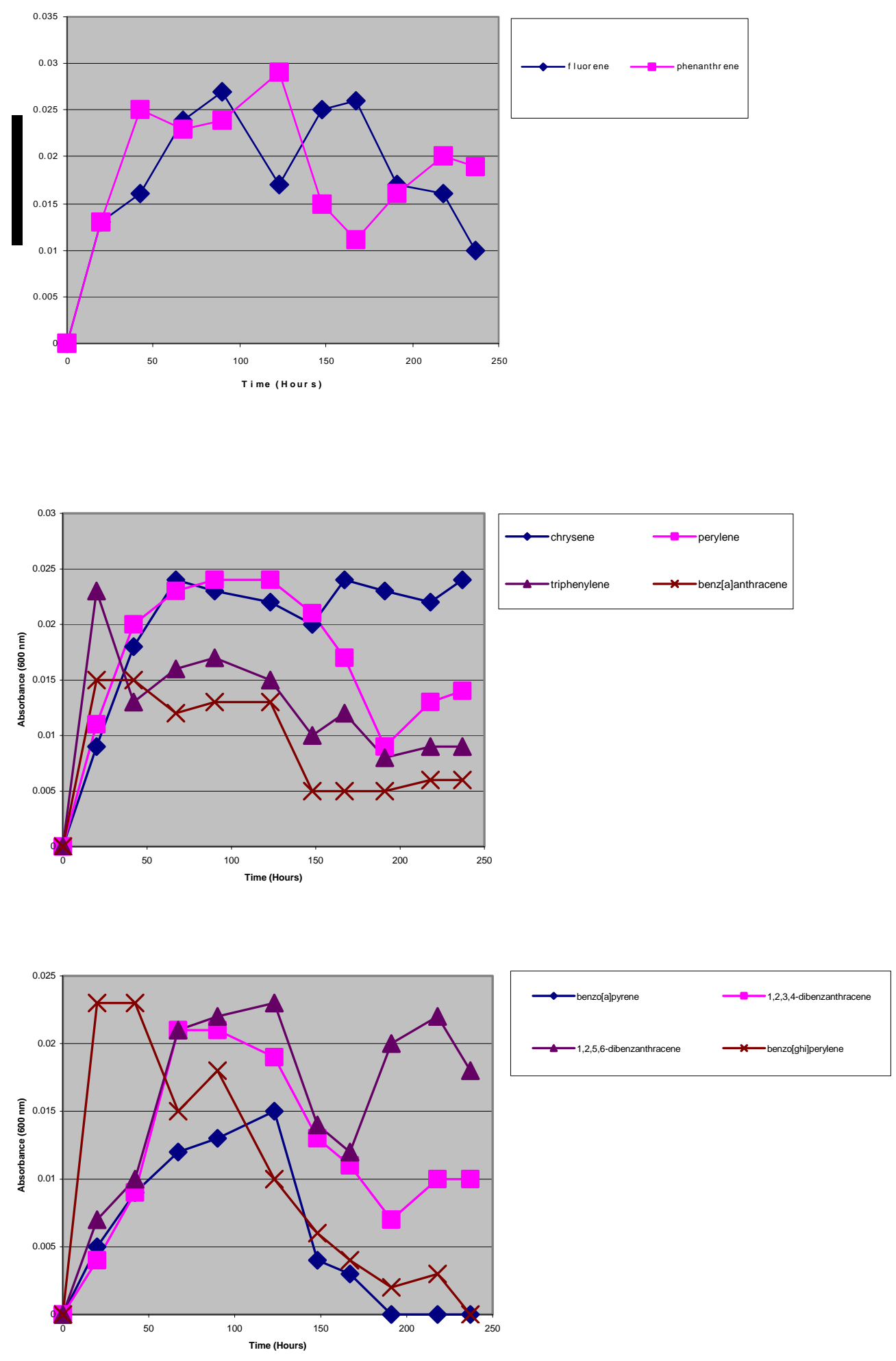

Figure 5 - Growth of Mycobacterium austroafricanum in 96-well microplates with various three-, four-, or five- and six-ring PAHs serving as a sole source of carbon and energy. 


\section{REFERENCES CITED}

Alley, J.F. and L.R. Brown. 2000. Use of Sublimation to Prepare Solid Microbial Media with Water-insoluble Substrates. Applied and Environmental Microbiology 66:439-442.

Beltran, F.J., M. Gonzalez, F.J. Rivas, and P. Alvarez. 1998. Fenton Reagent Advanced Oxidation of Polynuclear Aromatic Hydrocarbons in Water. Water, Air, and Soil Pollution 105:685-700.

Bigda, R.J. 1996. Fenton's Chemistry: An Effective Advanced Oxidation Process. Environmental Technology (May/June):34-39.

Davies, K.G. and R. Whitbread. 1989. In Vitro Studies of Siderophore Production by Wild Type and Rifampicin Resistant strains of Fluorescent Pseudomonads. Plant and Soil 116:123-125.

Gorden, R.W., T.C. Hazen, and C.B. Fliermans. 1993. Rapid Screening for Bacteria Capable of Degrading Toxic Organic Compounds. Journal of Microbiological Methods 18:339-347.

Lundanes, E. and T. Greibrokk. 1994. "Separation of fuels, heavy fractions, and crude oils into compound classes: A review.” J. High Ressolut. Chromatogr. 17: 197-202.

Sheldrick, B.H. and C. Wang. 1993. Particle Size Distribution. Pages 499-512 in M.R. Carter (ed), Soil Sampling and Methods of Analysis. Lewis Publishers, Boca Raton. 
APPENDIX -PUBLICATION 


\title{
Effects of Alkylphosphates and Nitrous Oxide on Microbial Degradation of Polycyclic Aromatic Hydrocarbons
}

\author{
BILL W. BOGAN,* LISA M. LAHNER, VESNA TRBOVIC, ANN M. SZAJKOVICS, \\ AND J. ROBERT PATEREK
}

Gas Technology Institute, Des Plaines, Illinois 60018

Received 20 November 2000/Accepted 19 February 2001

\begin{abstract}
We conducted a series of liquid-culture experiments to begin to evaluate the abilities of gaseous sources of nitrogen and phosphorus to support biodegradation of polycyclic aromatic hydrocarbons (PAHs). Nutrients examined included nitrous oxide, as well as triethylphosphate (TEP) and tributylphosphate (TBP). Cultures were established using the indigenous microbial populations from one manufactured gas plant (MGP) site and one crude oil-contaminated drilling field site. Mineralization of phenanthrene was measured under alternative nutrient regimes and was compared to that seen with ammoniacal nitrogen and $\mathbf{P O}_{4}$. Parallel cultures were used to assess removal of a suite of three- to five-ring PAHs. In summary, the abilities of the different communities to degrade PAH when supplemented with $\mathrm{N}_{2} \mathrm{O}$, TEP, and TBP were highly variable. For example, in the MGP soil, organic $P$ sources, especially TBP, supported a considerably higher degree of removal of low-molecular-weight $\mathrm{PAHs}$ than did $\mathrm{PO}_{4}$; however, loss of high-molecular-weight compounds was impaired under these conditions. The disappearance of most PAHs was significantly less in the oil field soil when organophosphates were used. These results indicate that the utility of gaseous nutrients for PAH bioremediation in situ may be limited and will very likely have to be assessed on a case-by-case basis.
\end{abstract}

Approximately 1,500 former manufactured gas plant (MGP) sites in the United States are estimated to exhibit contaminated soil and groundwater due to coal and oil gasification and liquefaction operations (9). Similarly, at least 700 identified sites in the United States are contaminated with creosote as a result of improper handling and disposal of materials during wood-preserving activities (18). Both of these classes of sites are considered to pose a significant potential health risk for humans and wildlife, since the wastes generated in these processes (primarily coal tars and related substances) contain numerous toxic, carcinogenic, and/or mutagenic compounds.

The most notable class of hazardous compounds found in both coal tar and its derivatives (e.g., creosote) is the polycyclic aromatic hydrocarbons, or PAHs $(19,20)$, which consist of two or more benzene rings fused into a single aromatic structure. Mammalian liver enzymes (cytochromes P-450 and epoxide hydrolase) oxidize certain PAHs to fjord- and bay-region diolepoxides $(2,11,17,29,30)$; these moieties form covalent adducts with DNA $(17,28)$. Therefore, many PAHs are genotoxic and/or carcinogenic $(1,2,8,14,23)$ and promote similar effects of other compounds (6). Thus, a total of 16 PAHs have been included on the U.S. Environmental Protection Agency (EPA)'s priority pollutant list (13).

Bioremediation has long been proposed as a treatment technology for the decontamination of PAH-contaminated soils. Numerous bacteria are known to catabolize various two-, three-, and four-ring PAHs as sole sources of carbon and energy (for a review, see reference 5), thus making them good candidate species for site remediation applications. The efficacy of bioremediation approaches, particularly when applied

* Corresponding author. Mailing address: Gas Technology Institute, 1700 South Mount Prospect Rd., Des Plaines, IL 60018. Phone: (847) 768-0719. Fax: (847) 768-0669. E-mail: bill.bogan@gastechnology.org. in situ, depends on overcoming any potential nutrient limitations within the soil system to be remediated. In the case of hydrocarbon-contaminated soils, the limiting nutrient is most frequently either phosphorus or nitrogen or, in some cases, both of these. This can be ameliorated via the subsurface injection of soluble nutrients; however, the resultant very high concentrations of nutrients in the immediate vicinity of such injection wells has been observed to lead to excessive localized microbial growth, with concomitant "biofouling" of the wells (4).

The use of gaseous nutrients ( $\mathrm{N}$ and $\mathrm{P}$ compounds with sufficiently high vapor pressures to allow their conversion to a gas under environmental conditions) has been demonstrated in situ as a means of better distributing nutrients throughout the system in support of soil bioremediation. Triethylphosphate (TEP) and tributylphosphate (TBP), although mildly toxic and corrosive irritants, are nonetheless the safest phosphorus compounds which can readily be gasified (in comparison with, for example, phosgene or the carcinogenic trimethylphosphate). They have thus been utilized as phosphorus sources $(4,21)$ in a patented process $(15,16)$. Similarly, gaseous nitrous oxide has been used to supply nitrogen $(4,21)$. The delivery of gaseous nutrients has been shown to enhance the in situ remediation of chlorinated solvents and volatile organic compounds (4, 21), as well as $\mathrm{C}_{4}-\mathrm{C}_{10}$ alkanes and monoaromatic hydrocarbons (e.g., benzene, toluene, ethylbenzene, and xylene) (24). It has not, however, been documented as a means of enhancing the remediation of PAH-contaminated soils.

This paper presents the results of liquid-culture studies of the abilities of organic phosphates (TEP and TBP) and $\mathrm{N}_{2} \mathrm{O}$ to support degradation of PAH by bacteria present in MGP and other petroleum-contaminated site soils. Liquid-culture conditions, although clearly not representative of field conditions, were chosen in order to evaluate microbial performance under 
TABLE 1. Initial levels of PAH in the soils incorporated in this study, as well as the $n, n$-dimethylformamide-solubilized extract of MGP soil which was added as a supplemental source of available PAH

\begin{tabular}{lrrr}
\hline \multirow{2}{*}{\multicolumn{1}{c}{ PAH }} & \multicolumn{3}{c}{ Concn (ppm) of PAH in: } \\
\cline { 2 - 3 } & \multicolumn{2}{c}{ Soils } & $\begin{array}{c}\text { Supplemental } \\
\text { extract }\end{array}$ \\
\cline { 2 - 3 } & MGP & Oil field & 1,172 \\
\hline Fluorene & 88 & 1.0 & 2,140 \\
Phenanthrene & 239 & 3.5 & 4,494 \\
Anthracene & 359 & 0.7 & 1,102 \\
Fluoranthene & 643 & 0.8 & 666 \\
Pyrene & 940 & 1.1 & 377 \\
Benz[a]anthracene & 168 & $<0.4$ & 387 \\
Chrysene & 182 & 4.3 & 316 \\
Benzo[ $b]$ fluoranthene & 82 & $<0.4$ & 247 \\
Benzo[ $k]$ fluoranthene & 51 & 1.2 & 277 \\
Benzo[ $a$ ]pyrene & 106 & $<0.5$ & 147 \\
Dibenz[ah]anthracene & 26 & $<0.4$ & 64 \\
Benzo[ghi]perylene & 14 & $<0.4$ & 140 \\
Indeno $(123$ - $c d$ )pyrene & 20 & $<0.4$ & \\
\hline
\end{tabular}

conditions of optimal bioavailability. In general, we have found that while removal of some PAHs in some soils does appear to be significantly stimulated through the use of alternative sources of $\mathrm{N}$ and $\mathrm{P}$, this effect is not universal. There appears to be considerable site-specific variability based on differences in microbiology, soil chemistry, and/or soil structure, implying that soil treatability evaluations will have to be conducted on a case-by-case basis. Our results will serve as a starting point for studies on the use of gaseous $\mathrm{N}$ and $\mathrm{P}$ sources to support PAH bioremediation in soil column microcosms which are more representative of site conditions.

\section{MATERIALS AND METHODS}

Soils. Soil samples were obtained from sites with a history of industrial activities leading to PAH contamination. The MGP soil is a loamy sand ( $86 \%$ sand, $5 \%$ clay, $9 \%$ silt) from a New Jersey site, whereas the oil field soil is a crude oil-contaminated sandy loam (63\% sand, $3 \%$ clay, $34 \%$ silt) obtained from the vicinity of a wellhead in a drilling field in southern Illinois. PAH concentrations for the two soils are given in Table 1 . The oil field soil, although very high (ca. $16 \%$ [data not shown]) in total petroleum hydrocarbons, actually contained relatively modest levels of $\mathrm{PAH}$, as can be seen in Table 1 . Each of these soils was air dried (to ca. 3\% moisture) and homogenized immediately prior to use.

Culture conditions. Homogenized soil samples $(500 \mathrm{mg})$ were mixed with 50 $\mathrm{ml}$ of sterile media $\left(0.1 \mathrm{ml}\right.$ of Wolfe's vitamins [2-mg $\cdot$ liter $^{-1}$ biotin, 2-mg liter ${ }^{-1}$ folic acid, $10-\mathrm{mg} \cdot$ liter $^{-1}$ pyridoxine $\mathrm{HCl}, 5-\mathrm{mg} \cdot$ liter $^{-1}$ thiamine $\mathrm{HCl}$, $5-\mathrm{mg} \cdot \operatorname{liter}^{-1}$ riboflavin, $5-\mathrm{mg} \cdot \operatorname{liter}^{-1}$ nicotinic acid, $5-\mathrm{mg} \cdot \operatorname{liter}^{-1}$ pantothenic acid, $0.1-\mathrm{mg} \cdot \operatorname{liter}^{-1}$ cyanocobalamine, 5 -mg $\cdot \operatorname{liter}^{-1} p$-aminobenzoic acid, 5 -mg $\cdot$ liter $^{-1}$ thioctic acid], $0.1 \mathrm{ml}$ of trace minerals [100-mg $\cdot \operatorname{liter}^{-1} \mathrm{ZnSO}_{4}, 300-\mathrm{mg}$. liter ${ }^{-1} \mathrm{H}_{3} \mathrm{BO}_{3}, 300-\mathrm{mg} \cdot$ liter $^{-1} \mathrm{CoCl}, 10-\mathrm{mg} \cdot$ liter $^{-1} \mathrm{CuCl}$ ], and $0.8 \mathrm{ml}$ of $\mathrm{N}$ - and P-free Winogradsky medium [pH 7.2] [62.5-g $\cdot \operatorname{liter}^{-1} \mathrm{MgSO}_{4} \cdot 7 \mathrm{H}_{2} \mathrm{O}, 31.25-\mathrm{g}$. liter ${ }^{-1} \mathrm{NaCl}, 1.25-\mathrm{g} \cdot$ liter $^{-1} \mathrm{FeSO}_{4}, 1.25-\mathrm{g} \cdot$ liter $^{-1} \mathrm{MnSO}_{4}$ ] per $100 \mathrm{ml}$ of sterile deionized water) in $125-\mathrm{ml}$ serum bottles. In order to assess the degree of $\mathrm{N}$ and $\mathrm{P}$ limitation on $\mathrm{PAH}$ degradation inherent in each soil, $\left[{ }^{14} \mathrm{C}\right]$ phenanthrene mineralization was measured in cultures of each of the three soils which received no supplemental $\mathrm{N}$ or $\mathrm{P}, \mathrm{N}$ only $\left(\right.$ as $\mathrm{NH}_{4} \mathrm{Cl}$ ), $\mathrm{P}$ only $\left(\right.$ as $\left.\mathrm{KH}_{2} \mathrm{PO}_{4}\right)$, or both $\mathrm{N}$ and $\mathrm{P}$. Six combinations were then investigated for $\mathrm{N}$ and $\mathrm{P}$ supplementation: $\mathrm{NH}_{4} \mathrm{Cl}$ plus $\mathrm{KH}_{2} \mathrm{PO}_{4} ; \mathrm{N}_{2} \mathrm{O}$ plus $\mathrm{KH}_{2} \mathrm{PO}_{4} ; \mathrm{NH}_{4} \mathrm{Cl}$ plus TEP; $\mathrm{NH}_{4} \mathrm{Cl}$ plus TBP; $\mathrm{N}_{2} \mathrm{O}$ plus TEP; and $\mathrm{N}_{2} \mathrm{O}$ plus TBP. Within each condition, duplicate cultures were employed. In all cases, addition of $\mathrm{N}$ and $\mathrm{P}$ sources was normalized on a molar basis to provide $9.2 \mathrm{mM} \mathrm{N}$ and $3.7 \mathrm{mM} \mathrm{P}$. When $\mathrm{N}_{2} \mathrm{O}$ was used, it was added by injection to sealed bottles. In order to ensure the presence of at least some bioavailable PAH, all cultures were also supplemented with $50 \mu$ l of a PAHcontaining extract from a second MGP soil (approx. 12,000 ppm of total PAH; Table 1) dissolved in $n, n$-dimethylformamide. One set of cultures (duplicates of each condition) was further supplemented with ${ }^{14} \mathrm{C}$-phenanthrene for mineral- ization determinations (see below), while one received no radiolabel and was used to simultaneously measure the extent of disappearance of multiple PAHs. Both sets of cultures were incubated at room temperature (approximately $25^{\circ} \mathrm{C}$ ) with shaking at $170 \mathrm{rpm}$. Poisoned controls (10 $\mathrm{mg}$ of $\mathrm{HgCl}_{2}$ per culture) were also conducted in duplicate.

Mineralization of ${ }^{14} \mathrm{C}$-PAH. $\mathrm{CO}_{2}$ traps were made by wrapping stainless steel wire around the necks of 12-by-32-mm borosilicate glass autosampler vials and pushing the wire through $20-\mathrm{mm}$ Teflon silicone-lined septa. These assemblies were placed in the serum bottles, which were then crimped with aluminum seals. Syringes were used to inject $1 \mathrm{ml}$ of $0.5 \mathrm{M} \mathrm{NaOH}$ into each $\mathrm{CO}_{2}$ trap. Periodically, the $\mathrm{CO}_{2}$-containing $\mathrm{NaOH}$ solution was withdrawn from the traps, mixed with $5 \mathrm{ml}$ of Ultima Gold high-flashpoint liquid scintillation cocktail (Packard, Meriden, Conn.) and counted in a liquid scintillation counter (Packard model 2200CA Tri-Carb). Fresh $\mathrm{NaOH}$ was then added to the $\mathrm{CO}_{2}$ traps. Cultures containing ${ }^{14} \mathrm{C}$-phenanthrene typically received ca. 80,000 to $100,000 \mathrm{dpm}$ of $\mathrm{PAH}$ in $20 \mu \mathrm{l}$ of methanol.

Extraction and high-pressure liquid chromatography (HPLC) analysis. Soil samples were centrifuged $(10 \mathrm{~min}, 5,000 \times g)$ in stainless-steel containers to separate solid and aqueous phases. Soil solids were mixed with anhydrous sodium sulfate (1:1) and ground with a mortar and pestle to form a fine powder. Sonication was performed according to EPA method 3550A (27) using 1:1 hexane-acetone $(30 \mathrm{ml})$ as the solvent and was repeated three times. The extracts were combined and vacuum filtered before evaporation. The aqueous phases of various cultures were extracted threefold with methylene chloride as per EPA method 3510B (27). These extracts were then dried by passage through anhydrous sodium sulfate. Both solid and aqueous extracts were evaporated to dryness under a stream of $\mathrm{N}_{2}$ in a Turbovap evaporator (Zymark, Hopkinton, Mass.) and exchanged into acetonitrile (ACN) $(1 \mathrm{ml})$. Ten microliters of this solution was analyzed by reverse-phase HPLC (EPA method 8310 [27]) using a Supelcosil LC-PAH column (15 cm by $4.6 \mathrm{~mm}$ ) and a Waters HPLC system coupled to a diode-array detector (Waters model 996). The following gradient was used, with a flow rate of $1.5 \mathrm{ml} \cdot \mathrm{min}^{-1}$ throughout: $0 \mathrm{~min}, 60 \% \mathrm{H}_{2} \mathrm{O}-40 \% \mathrm{ACN} ; 25 \mathrm{~min}$, $100 \% \mathrm{ACN}$ (hold for $2 \mathrm{~min}$ ); $33 \mathrm{~min}, 60 \% \mathrm{H}_{2} \mathrm{O}-40 \% \mathrm{ACN}$. Identities of individual PAHs were verified by comparing the retention times and the absorbance spectra and quantified by comparison with five-point standard curves (all $r^{2}$ values were $>0.988$ ).

Chemicals. $\left[9-{ }^{14} \mathrm{C}\right]$ phenanthrene (reported purity, 98\%) was purchased from Sigma (St. Louis, Mo.). TEP (99\% pure) and TBP (98\%) were purchased from Aldrich (Milwaukee, Wis.); $\mathrm{N}_{2} \mathrm{O}$ (ultra-high purity) was from Matheson Gas Products (Joliet, Ill.). $\mathrm{NH}_{4} \mathrm{Cl}$ and $\mathrm{KH}_{2} \mathrm{PO}_{4}$ were purchased from Mallinckrodt Chemicals (Paris, Ky.), and $\mathrm{NaOH}$ and HPLC-grade solvents were purchased from Fisher Chemicals (Fairway, N.J.). Authentic PAH standards for use in HPLC analysis were obtained from Ultra Scientific (Kingstown, R.I.).

\section{RESULTS AND DISCUSSION}

Nutrient limitations were assessed for each site soil by determining the degree of phenanthrene mineralization which occurred in the absence of any supplemental $\mathrm{N}$ or $\mathrm{P}$; this was then compared to that which was supported by either nutrient singly or when the two were combined. Data for these trials are shown in Fig. 1. Both soils were strongly nutrient limited. The MGP soil showed an especially strong $\mathrm{N}$ limitation and a $\mathrm{P}$ limitation which was also significant, while the oil field soil was greatly limited by both $\mathrm{N}$ and $\mathrm{P}$; in this case, neither nutrient alone was capable of enhancing ${ }^{14} \mathrm{CO}_{2}$ release at all relative to results with unsupplemented conditions.

Cultures of the microbial communities from the two soils were examined for their ability to mineralize phenanthrene under various conditions of $\mathrm{N}$ and $\mathrm{P}$ supplementation. We also determined, using reverse-phase HPLC, disappearance of a range of three- to six-ring PAHs from cultures under the same set of nutrient supplementation conditions.

In the case of the MGP soil, there was little effect of varying nutrient compositions on mineralization of spiked $\left[{ }^{14} \mathrm{C}\right]$ phenanthrene, as can be seen in Fig. 2. All nutrient regimes examined sustained between 50 and $70 \%$ conversion to $\mathrm{CO}_{2}$, with the only significant difference between the different treatments 


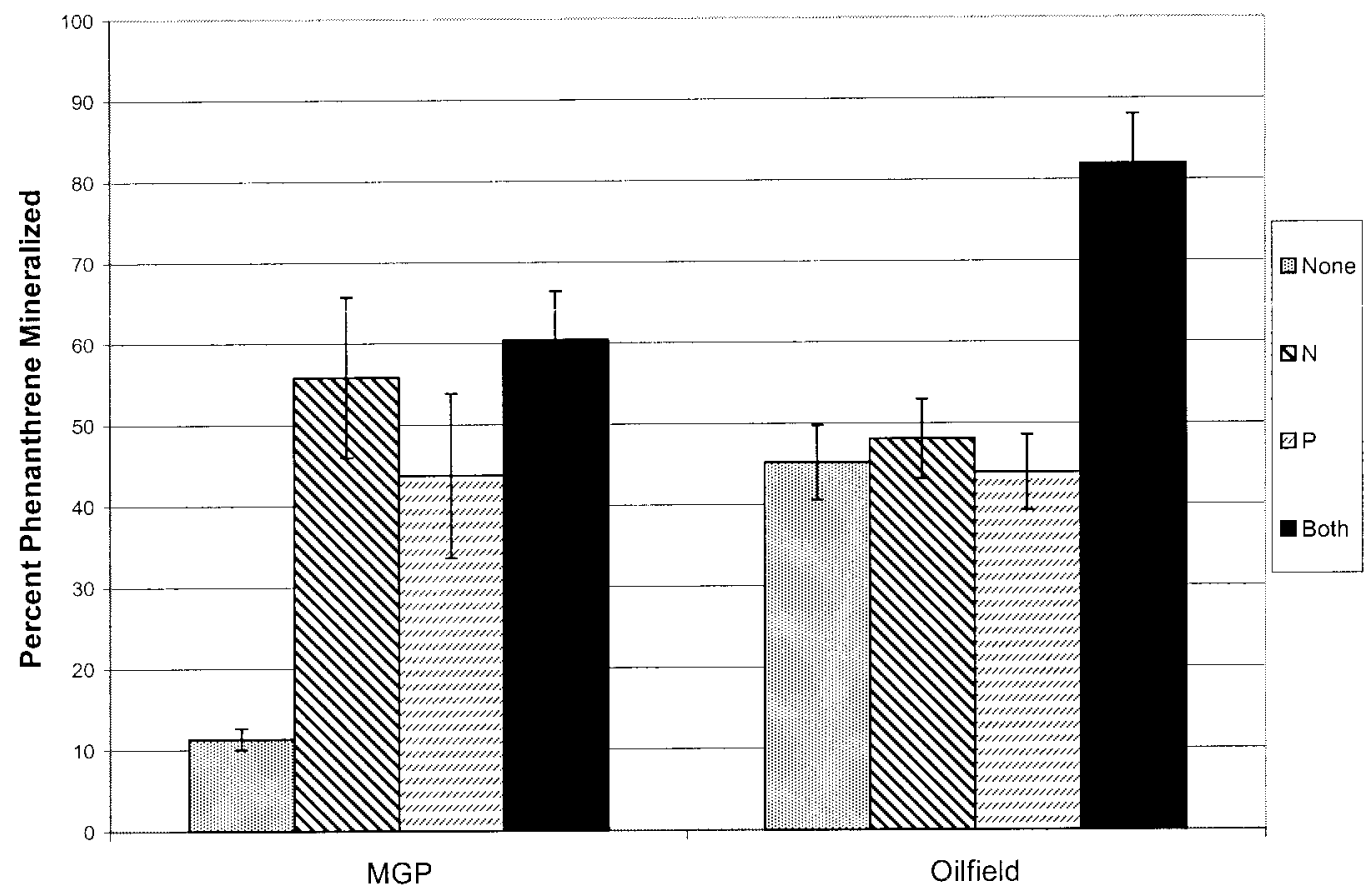

FIG. 1. Extent of $\left[{ }^{14} \mathrm{C}\right]$ phenanthrene mineralization (during a total incubation time of 5 weeks) in each soil in the absence of $\mathrm{N}$ or $\mathrm{P}$ supplementation or when $\mathrm{NH}_{4} \mathrm{Cl}$ and $\mathrm{KH}_{2} \mathrm{PO}_{4}$ were added either singly or in combination.

being a slightly longer lag time prior to mineralization in the three conditions in which $\mathrm{N}_{2} \mathrm{O}$ served as the nitrogen source. Cultures receiving $\mathrm{HgCl}_{2}(10 \mathrm{mg})$ were still capable of mineralizing $7.3 \%$ of the input phenanthrene.

Under conventional nutrient additions $\left(\mathrm{NH}_{4}\right.$ and $\left.\mathrm{PO}_{4}\right)$, the microbial community present in the MGP soil displayed sig- nificant removal of all three-ring compounds examined, as well as some elimination of several four- and five-ring PAHs (Table 2). A separate experiment, in which mineralization of ${ }^{14} \mathrm{C}$ pyrene was measured (data not shown), indicated that no mineralization of this PAH occurred; thus, it seems possible that the loss of pyrene seen in this soil may be due to cometabolic

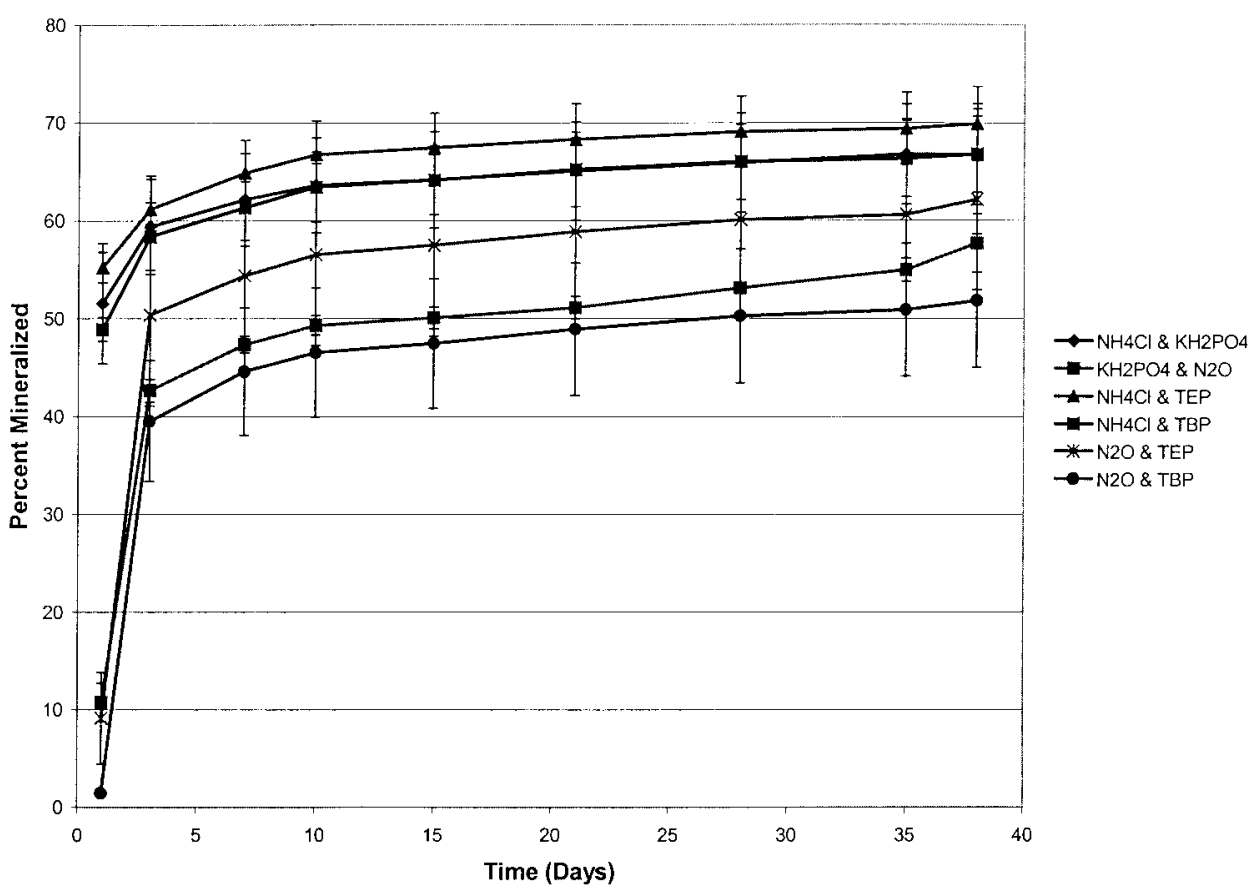

FIG. 2. Mineralization of phenanthrene and pyrene by the microbial community associated with the MGP soil under various conditions of N and P supplementation. 
TABLE 2. Percent recovery (versus time-zero levels) of selected three- to five-ring PAHs from the MGP soil after 38 days of treatment under various conditions of $\mathrm{N}$ and $\mathrm{P}$ supplementation

\begin{tabular}{|c|c|c|c|c|c|c|c|}
\hline \multirow{2}{*}{$\mathrm{PAH}^{a}$} & \multicolumn{7}{|c|}{$\%$ Recovery of PAH after treatment with ${ }^{b}:$} \\
\hline & $\mathrm{NH}_{4}+\mathrm{PO}_{4}$ & $\mathrm{~N}_{2} \mathrm{O}+\mathrm{PO}_{4}$ & $\mathrm{NH}_{4}+\mathrm{TEP}$ & $\mathrm{NH}_{4}+\mathrm{TBP}$ & $\mathrm{N}_{2} \mathrm{O}+\mathrm{TEP}$ & $\mathrm{N}_{2} \mathrm{O}+\mathrm{TBP}$ & Poison (killed controls) \\
\hline FLU & $16 \pm 0$ & $36 \pm 11$ & $46 \pm 6$ & $12 \pm 4$ & $51 \pm 13$ & $51 \pm 5$ & $76 \pm 6$ \\
\hline PHE & $24 \pm 2$ & $35 \pm 2$ & $52 \pm 4$ & $7 \pm 2$ & $45 \pm 8$ & $36 \pm 1$ & $107 \pm 1$ \\
\hline ANT & $25 \pm 6$ & $45 \pm 7$ & $44 \pm 3$ & $6 \pm 0$ & $51 \pm 7$ & $102 \pm 8$ & $124 \pm 4$ \\
\hline FLA & $63 \pm 5$ & $109 \pm 12$ & $118 \pm 5$ & $67 \pm 13$ & $111 \pm 14$ & $131 \pm 9$ & $112 \pm 4$ \\
\hline PYR & $86 \pm 15$ & $116 \pm 5$ & $137 \pm 8$ & $104 \pm 21$ & $128 \pm 11$ & $132 \pm 15$ & $118 \pm 4$ \\
\hline BAA & $90 \pm 11$ & $108 \pm 7$ & $140 \pm 7$ & $120 \pm 24$ & $128 \pm 7$ & $123 \pm 6$ & $105 \pm 4$ \\
\hline CHR & $90 \pm 10$ & $143 \pm 14$ & $140 \pm 11$ & $122 \pm 21$ & $128 \pm 3$ & $115 \pm 12$ & $97 \pm 2$ \\
\hline $\mathrm{BBF}$ & $99 \pm 15$ & $95 \pm 12$ & $162 \pm 15$ & $144 \pm 26$ & $143 \pm 9$ & $145 \pm 8$ & $135 \pm 20$ \\
\hline BKF & $68 \pm 12$ & $125 \pm 5$ & $105 \pm 10$ & $94 \pm 18$ & $101 \pm 4$ & $97 \pm 10$ & $85 \pm 10$ \\
\hline BAP & $86 \pm 13$ & $132 \pm 13$ & $149 \pm 14$ & $124 \pm 28$ & $128 \pm 4$ & $121 \pm 5$ & $105 \pm 8$ \\
\hline
\end{tabular}

${ }^{a}$ FLU, fluorene; PHE, phenanthrene; ANT, anthracene; FLA, fluoranthene; PYR, pyrene; BAA, benz[ $\left.a\right]$ anthracene; CHR, chrysene; BBF, benzo[b]fluoranthene; $\mathrm{BKF}$, benzo $[k]$ fluoranthene; BAP, benzo $[a]$ pyrene.

${ }^{b}$ Values are given as means \pm the standard deviations.

effects (7), which may also account for the loss of other fourand five-ring compounds. No loss of six-ring PAHs was observed in this soil (data not shown). The data in Table 2 clearly show that substitution of alternative $\mathrm{N}$ and $\mathrm{P}$ sources does not, in most cases, enhance microbial PAH degradation in this soil. The combination of $\mathrm{NH}_{4}$ and TBP results in enhanced removal of phenanthrene and anthracene (relative to results with $\mathrm{NH}_{4}$ and $\mathrm{PO}_{4}$ ); however, losses of fluorene and fluoranthene are no greater under these conditions, and four- and five-ring compounds are unaffected. Most other nutrient regimes supported degradation of only the most labile compounds (fluorene, phenanthrene, and anthracene).

In the crude oil-contaminated wellhead soil, as in the MGP soil, mineralization of phenanthrene was greatest in the $\mathrm{NH}_{4} \mathrm{Cl}$ plus- $\mathrm{KH}_{2} \mathrm{PO}_{4}$ cultures (Fig. 3), again exceeding $80 \%$. In this soil, use of any of the alternative nutrients substantially reduced the mineralization of phenanthrene. Pairwise comparisons of the different conditions showed clear trends, since all three of the $\mathrm{NH}_{4}$-containing cultures outperformed their $\mathrm{N}_{2} \mathrm{O}$ containing counterparts. Furthermore, the trend in which $\mathrm{PO}_{4}$ outperformed TEP which, in turn, outperformed TBP was true for both the $\mathrm{NH}_{4}$ and $\mathrm{N}_{2} \mathrm{O}$ sets of cultures. Killed controls evolved $1.7 \%$ of the input ${ }^{14} \mathrm{C}$ as $\mathrm{CO}_{2}$.

The extent of PAH removal from the oil field soil was considerably higher than that from the MGP site soil. Table 3 shows that nearly all compounds examined were significantly removed from this soil (which, as described above, is strongly $\mathrm{N}$ and $\mathrm{P}$ limited for mineralization of phenanthrene) under the $\mathrm{NH}_{4}$-plus- $\mathrm{PO}_{4}$ supplementation; this includes five-ring PAHs. Again, inasmuch as no significant mineralization of pyrene was

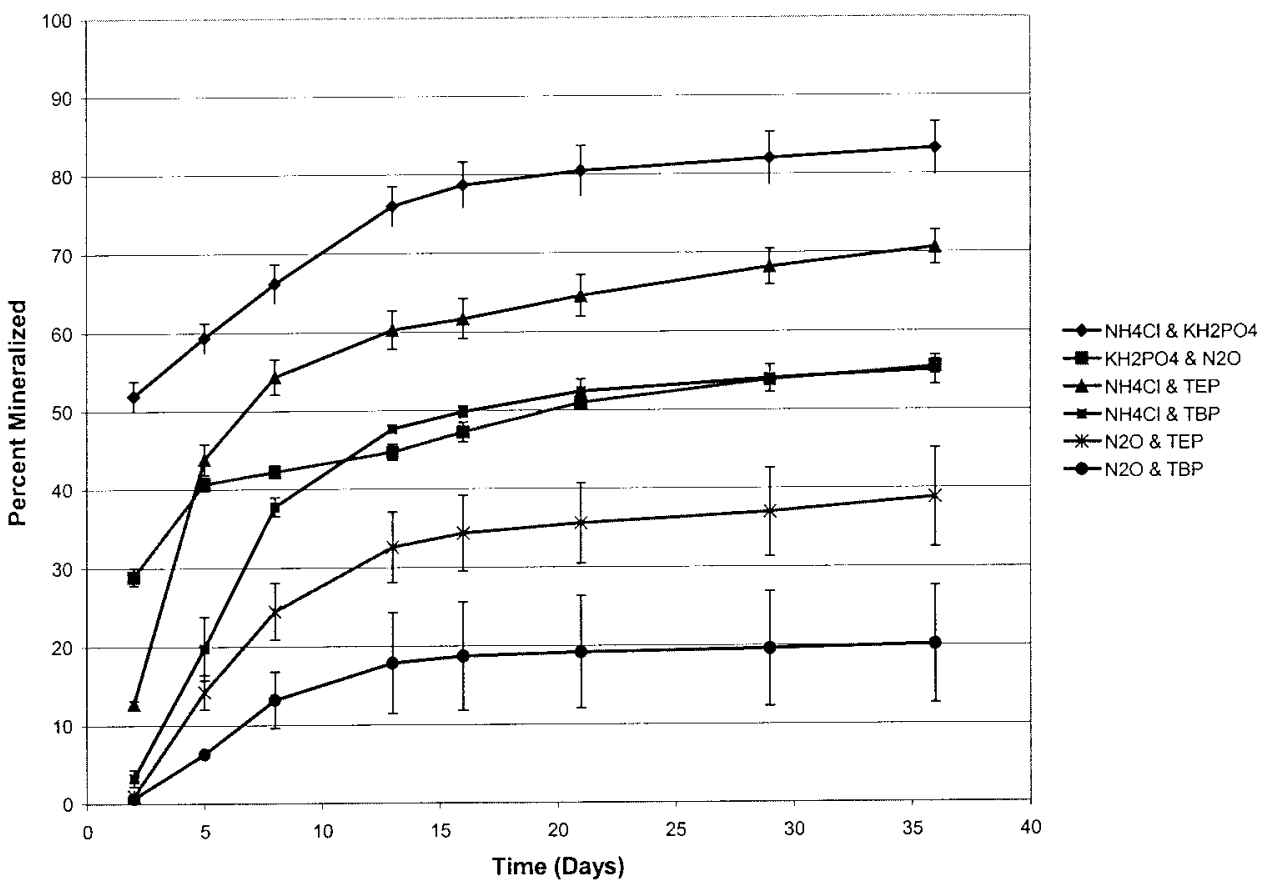

FIG. 3. Mineralization of phenanthrene and pyrene by the microbial community associated with the crude oil-contaminated oil field soil under various conditions of $\mathrm{N}$ and $\mathrm{P}$ supplementation. 
TABLE 3. Percent recovery (versus time-zero levels) of selected three- to five-ring PAHs from the oil field soil after 38 days of treatment under various conditions of $\mathrm{N}$ and $\mathrm{P}$ supplementation

\begin{tabular}{|c|c|c|c|c|c|c|c|}
\hline \multirow{2}{*}{$\mathrm{PAH}^{a}$} & \multicolumn{7}{|c|}{$\%$ Recovery of PAH after treatment with ${ }^{b}:$} \\
\hline & $\mathrm{NH}_{4}+\mathrm{PO}_{4}$ & $\mathrm{~N}_{2} \mathrm{O}+\mathrm{PO}_{4}$ & $\mathrm{NH}_{4}+\mathrm{TEP}$ & $\mathrm{NH}_{4}+\mathrm{TBP}$ & $\mathrm{N}_{2} \mathrm{O}+\mathrm{TEP}$ & $\mathrm{N}_{2} \mathrm{O}+\mathrm{TBP}$ & Poison (killed controls) \\
\hline FLU & $0 \pm 0$ & $3 \pm 2$ & $0 \pm 0$ & $5 \pm 1$ & $2 \pm 1$ & $5 \pm 4$ & $95 \pm 8$ \\
\hline PHE & $0 \pm 0$ & $1 \pm 0$ & $1 \pm 0$ & $1 \pm 1$ & $1 \pm 1$ & $2 \pm 2$ & $97 \pm 12$ \\
\hline ANT & $0 \pm 0$ & $1 \pm 1$ & $0 \pm 0$ & $1 \pm 0$ & $3 \pm 1$ & $1 \pm 1$ & $72 \pm 7$ \\
\hline FLA & $2 \pm 1$ & $4 \pm 1$ & $12 \pm 1$ & $43 \pm 4$ & $58 \pm 4$ & $43 \pm 13$ & $101 \pm 10$ \\
\hline PYR & $6 \pm 5$ & $35 \pm 9$ & $104 \pm 5$ & $71 \pm 7$ & $132 \pm 14$ & $99 \pm 29$ & $100 \pm 13$ \\
\hline BAA & $7 \pm 4$ & $37 \pm 13$ & $36 \pm 1$ & $74 \pm 12$ & $85 \pm 5$ & $82 \pm 6$ & $74 \pm 7$ \\
\hline CHR & $14 \pm 9$ & $12 \pm 2$ & $34 \pm 2$ & $82 \pm 11$ & $110 \pm 20$ & $102 \pm 14$ & $108 \pm 11$ \\
\hline $\mathrm{BBF}$ & $17 \pm 7$ & $72 \pm 9$ & $90 \pm 4$ & $87 \pm 18$ & $104 \pm 6$ & $92 \pm 15$ & $68 \pm 7$ \\
\hline BKF & $7 \pm 4$ & $48 \pm 13$ & $99 \pm 10$ & $104 \pm 14$ & $107 \pm 15$ & $107 \pm 14$ & $93 \pm 10$ \\
\hline BAP & $27 \pm 19$ & $76 \pm 15$ & $90 \pm 8$ & $72 \pm 11$ & $86 \pm 10$ & $87 \pm 16$ & $73 \pm 14$ \\
\hline DAA & $58 \pm 43$ & $108 \pm 38$ & $154 \pm 22$ & $65 \pm 20$ & $79 \pm 20$ & $98 \pm 17$ & $72 \pm 14$ \\
\hline
\end{tabular}

${ }^{a}$ DAA, dibenz $[a h]$ anthracene. For other abbreviations, see Table 2, footnote $a$.

${ }^{b}$ Values are given as means \pm the standard deviations.

seen in this case (data not shown), it seems possible that some of the losses of high-molecular-weight (HMW) PAHs are cometabolic in nature. As with the MGP soil, inclusion of an alternative source of either $\mathrm{N}$ or $\mathrm{P}$ significantly impeded $\mathrm{PAH}$ removal for many compounds, although essentially complete removal of some (phenanthrene, anthracene, and fluorene) did still occur under all nutrient regimes. In the case of this soil, it appears that $\mathrm{N}_{2} \mathrm{O}$ is more capable of serving as a nitrogen source than either TBP or TEP is as a phosphorus source, since the $\mathrm{N}_{2} \mathrm{O}-\mathrm{PO}_{4}$ combination supports a broader and more extensive removal of HMW species than do any conditions including either of the alkyphosphates.

Among the soils examined in this work, it is clear that the bacteria present in the oil field soil were more adept at removing PAHs, including the HMW species. This is interesting because although the soil in question has very high levels of total petroleum hydrocarbons (approximately 16.2\%), the levels of PAHs are actually quite low. As can be seen in Table 1, the initial levels of total PAH in this soil were no higher than approximately $20 \mathrm{ppm}$. The superior ability of the microbial community in this soil to degrade PAH may therefore be the result of a long period of constant or recurring low-level exposure to these compounds.

It has been stated by other authors that the $\mathrm{P}$ contained in organophosphorus molecules, such as TEP, is not available to all microbes (4). In fact, the selective pressure exerted through the addition of TEP was looked upon as an advantage in the case of cometabolic remediation of TCE- and PCE-contaminated groundwaters by type II methanotrophs, which are capable of utilizing TEP as a phosphorus source. Coinjection of TEP and methane into a solvent-contaminated aquifer thus caused up to 1,000-fold increases in the activities of these bacteria, while the total bacterial biomass remained essentially unchanged $(4,21)$. Literature on the taxonomic distribution and extent of TEP and TBP utilization is limited. A mixed culture of Pseudomonas strains was capable of releasing $\mathrm{PO}_{4}$ from TEP; this was examined for the removal (via precipitation of $\mathrm{HUO}_{2} \mathrm{PO}_{4}$ ) of $\mathrm{UO}_{2}{ }^{2+}$ from uranium-contaminated mine wastewaters (26). Similarly, other Pseudomonas strains (22), as well as strains of Hyphomicrobium (10) and Acinetobacter (25), are known to be able to utilize TBP, TEP, and/or trimethylphosphate as sole sources of $\mathrm{P}$.
Our results, however, imply that the ability to utilize TEP or TBP and $\mathrm{N}_{2} \mathrm{O}$, at least under slurry conditions, is not a universal attribute among PAH-degrading bacteria. The ability of alternative nutrient combinations to actually enhance $\mathrm{PAH}$ removal relative to results with $\mathrm{NH}_{4}$-plus- $\mathrm{PO}_{4}$-supplemented cultures seems to have been restricted to the MGP soil and was, even in this case, seen only with lower-molecular-weight compounds.

It is possible that some of our results were due to the effects of the solubility of TEP and TBP on their availability to PAHdegrading bacteria. As a consequence of its longer aliphatic groups and resultant greater hydrophobicity, TBP is more resistant to solubilization than TBP; for example, we observed that the former tended to form persistent globules in the culture media, whereas the latter did not. It is, however, difficult to attribute these observations to the effects of solubility alone, since the same adaptations (e.g., lipid-rich outer cell layers, production of biosurfactants) which confer the capability to take up HMW PAHs upon bacteria such as Mycobacterium (3, 12) and Sphingomonas (3) would be expected to have the same effect on TBP. It is therefore possible that the increased removal of some PAHs which was occasionally seen with TBP (Table 2), as well as the high mineralization of phenanthrene supported by both alkylphosphates in the MGP soil (Fig. 2), may reflect the participation of some of these bacteria. These species may actually be favored by the use of more hydrophobic nutrient sources, both because of increased compatibility with their uptake systems and a more favorable distribution within the microcosm. Hydrophobic nutrient sources, such as TBP, might be expected to partition onto soil organic matter, which might be beneficial to organisms such as those listed above, many of which tend to be adherent in nature (3). We have isolated several Sphingomonas strains from these two soils (3a); further examination of these isolates' relative abilities to utilize these alternative nutrient sources may help to address these questions.

The diffusivity of TEP and TBP is approximately 5 orders of magnitude higher in the gaseous phase than when these compounds are dissolved in water (4). Thus distribution would be expected to improve somewhat in vadose soil $(4,21)$, and the issue of the availability of $\mathrm{P}$ to soil surface adherents should be less of a factor than it may have been in these preliminary 
experiments. The results of the experiments described here indicate that it may not always be feasible to support remediation of PAH-contaminated soils with gaseous sources of $\mathrm{N}$ and $\mathrm{P}$ and that a great deal of site-specific variability can be expected. It is clear, however, that a true conclusion regarding the applicability of gaseous $\mathrm{N}$ and $\mathrm{P}$ supplements to in situ soil remediation will require soil column experiments which will better approximate the environmental conditions and behavior of bacteria in the vadose zone. It will also require a better understanding of which members of microbial communities involved in $\mathrm{PAH}$ degradation thrive and function under the different regimes and whether or not conditions can be devised to better optimize the performance of the entire community. Experiments in these areas are ongoing in this laboratory.

\section{ACKNOWLEDGMENTS}

This work was supported by research contract DE-AC26$99 B C 15223$ from the United States Department of Energy and by contract 8054 from the Gas Research Institute.

We thank Kevin Kayser of GTI for critical evaluation of the manuscript.

\section{REFERENCES}

1. Allen-Hoffmann, B. L., and J. G. Rheinwald. 1984. Polycyclic aromatic hydrocarbon mutagenesis of human epidermal keratinocytes in culture. Proc. Natl. Acad. Sci. USA 81:7802-7806.

2. Amin, S., J. Krzeminski, A. Rivenson, C. Kurtzke, S. S. Hecht, and K. El-Bayoumi. 1995. Mammary carcinogenicity in female CD rats of fjord region diol epoxides of benzo $[c]$ phenanthrene, benzo $[g]$ chrysene and dibenzo $[a, l]$ pyrene. Carcinogenesis 16:1971-1974.

3. Bastiaens, L., D. Springael, P. Wattiau, H. Harms, R. deWachter, H. Verachtert, and L. Diels. 2000. Isolation of adherent polycyclic aromatic hydrocarbon (PAH)-degrading bacteria using PAH-sorbing carriers. Appl. Environ. Microbiol. 66:1834-1843.

3a.Bogan, B. W., L. M. Lahner, and J. R. Paterek. Limited roles for salicylate and phthalate in bacterial PAH bioremediation. Bioremediat. J., in press.

4. Brockman, F. J., W. Payne, D. J. Workman, A. Soong, S. Manley, and T. C. Hazen. 1995. Effect of gaseous nitrogen and phosphorus injection on in situ bioremediation of a trichloroethylene-contaminated site. J. Hazard. Mater. 41:287-298.

5. Cerniglia, C. E. 1992. Biodegradation of polycyclic aromatic hydrocarbons. Biodegradation 3:351-368.

6. Chadwick, R. W., S. E. George, M. J. Kohan, R. W. Williams, J. C. Allison, D. L. Talley, Y. O. Hayes, and J. Chang. 1995. Potentiation of 2,6-dinitrotoluene genotoxicity in Fischer 344 rats by pretreatment with coal tar creosote. J. Toxicol. Environ. Health 44:319-336.

7. Chen, S.-H., and M. D. Aitken. 1999. Salicylate stimulates the degradation of high-molecular weight polycyclic aromatic hydrocarbons by Pseudomonas saccharophila P15. Environ. Sci. Technol. 33:435-439.

8. Djomo, J. E., V. Ferrier, L. Gauthier, C. Zoll-Moreux, and J. Marty. 1995. Amphibian micronucleus test in vivo: evaluation of the genotoxicity of some major polycyclic aromatic hydrocarbons found in a crude oil. Mutagenesis 10:223-226.

9. Eng, R. 1985. Survey of town gas and by-product production and locations in the US (1880-1950). U.S. Environmental Protection Agency Air and Energy Engineering Research Laboratory, Research Triangle Park, N.C.

10. Ghisalba, O., M. Kuenzi, G. M. Ramos Tombo, and H. P. Schar. 1987. Microbial degradation and utilisation of selected organophosphorus compounds: strategies and applications. Chimia 41:206-215.

11. Glatt, H., A. Piee, K. Pauly, T. Steinbrecher, R. Schrode, F. Oesch, and A.
Seidel. 1991. Fjord- and bay-region diol-epoxides investigated for stability, SOS induction in Escherischia coli, and mutagenicity in Salmonella typhimurium and mammalian cells. Cancer Res. 51:1659-1667.

12. Heitkamp, M. A., W. Franklin, and C. E. Cerniglia. 1988. Microbial metabolism of polycyclic aromatic hydrocarbons: isolation and characterization of a pyrene-degrading bacterium. Appl. Environ. Microbiol. 54:2549-2555.

13. Keith, L. H., and W. A. Telliard. 1979. Priority pollutants. I. A perspective view. Environ. Sci. Technol. 13:416-423.

14. Levin, W., D. R. Thakker, A. W. Wood, R. L. Chang, R. E. Lehr, D. M. Jerina, and A. H. Conney. 1978. Evidence that benzo[a]anthracene 3,4-diol-1,2epoxide is an ultimate carcinogen on mouse skin. Cancer Res. 38:1705-1710.

15. Looney, B. B., S. M. Pfiffner, T. J. Phelps, K. H. Lombard, T. C. Hazen, and J. W. Borthen. May 1998. Apparatus and method for phosphate-accelerated bioremediation. U.S. patent 5,753,109.

16. Looney, B. B., K. H. Lombard, T. C. Hazen, S. M. Pfiffner, T. J. Phelps, and J. W. Borthen. January 1996. Method for phosphate-accelerated bioremediation. U.S. patent 5,480,549.

17. Melikian, A. A., K. A. Prahalad, S. Amin, and S. S. Hecht. 1991. Comparative DNA binding of polynuclear aromatic hydrocarbons and their dihydrodiol and bay region diolepoxide metabolites in newborn mouse lung and liver. Carcinogenesis 12:1665-1670.

18. Mueller, J. G., P. J. Chapman, and P. H. Pritchard. 1989. Creosote-contaminated sites: their potential for bioremediation. Environ. Sci. Technol. 23: 1197-1201.

19. Nestler, F. H. M. 1974. The characterization of wood-preserving creosote by physical and chemical methods of analysis. U.S. Department of Agriculture Forest Service research paper FPL 195. U.S. Department of Agriculture Forest Service Forest Products Laboratory, Madison, Wis.

20. Nishioka, M., H.-C. Chang, and M. L. Lee. 1986. Structural characteristics of polycyclic aromatic hydrocarbon isomers in coal tars and combustion products. Environ. Sci. Technol. 20:1023-1027.

21. Palumbo, A. V., S. P. Scarborough, S. M. Pfiffner, and T. J. Phelps. 1995. Influence of nitrogen and phosphorus on the in situ bioremediation of trichloroethylene. Appl. Biochem. Biotechnol. 51/52:635-647.

22. Rosenberg, A., and M. Alexander. 1979. Microbial cleavage of various organophosphorus insecticides. Appl. Environ. Microbiol. 37:886-891.

23. Salagovič, J., I. Kalina, and K. Dubayová. 1995. Induction of single strand DNA breaks in workers professionally exposed to polycyclic aromatic hydrocarbons. Neoplasma 42:115-118.

24. Shamory, B. D., A. W. Lawrence, D. L. Miller, J. A. Miller, R. L. Weightman, R. M. Raetz, and T. D. Hayes. 1995. In situ bioremediation of a former natural gas dehydrator site using bioventing/biosparging, p. 587-599. In Proceedings of the SPE/EPA Exploration \& Production Environmental Conference. Society of Petroleum Engineers, Richardson, Tex.

25. Stoner, D. L., and A. J. Tien. September 1995. Method and compositions for the degradation of tributyl phosphate in chemical waste mixtures. U.S. patent $5,453,375$

26. Thomas, R. A. P., and L. E. Macaskie. 1998. The effect of growth conditions on the biodegradation of tributyl phosphate and potential for the remediation of acid mine drainage waters by a naturally-occurring mixed microbial culture. Appl. Microbiol. Biotechnol. 49:202-209.

27. U.S. Environmental Protection Agency. 1994. Test methods for evaluating solid waste. Vol. IB: Laboratory manual physical/chemical methods. Office of Solid Waste and Emergency Response, U.S. Environmental Protection Agency, Washington, D.C.

28. Walsh, P., C. el Aldouni, M. J. Mukhopadhyay, G. Viel, D. Nadeau, and G. G. Poirier. 1995. ${ }^{32} \mathrm{P}$-postlabeling determination of DNA adducts in the earthworm Lumbricus terrestris exposed to PAH-contaminated soils. Bull. Environ. Contam. Toxicol. 54:654-661.

29. Wood, A. W., R. L. Chang, W. Levin, R. E. Lehr, M. Schaefer-Ridder, J. M. Karle, D. M. Jerina, and A. H. Conney. 1977. Mutagenicity and cytotoxicity of benz $[a]$ anthracene diol epoxides and tetrahydro-epoxides: exceptional activity of the bay region 1,2-epoxides. Proc. Natl. Acad. Sci. USA 74:27462750 .

30. Wood, A. W., R. L. Chang, W. Levin, D. E. Ryan, P. E. Thomas, H. D. Mah, J. M. Karle, H. Yagi, D. M. Jerina, and A. H. Conney. 1979. Mutagenicity and tumorigenicity of phenanthrene and chrysene epoxides and diol epoxides. Cancer Res. 39:4069-4077. 